\title{
DAKWAH HALAQAH PONDOK PESANTREN AS'ADIYAH PUSAT SENGKANG
}

\author{
Besse Wahida \\ Institut Agama Islam Negeri (IAIN) Pontianak \\ Email: Besse_wahida@gmail.com
}

\begin{abstract}
Halaqah Da'wah is one of the models of da'wah delivery that is widely used in the spread of Islamic teaching in Indonesia. Central Board of Pesantren As'adiyah in Sengkang becames one of the Islamic education institutions which was born from a halaqah study conducted by Anregurutta Fungngaji Sade, the founder of As'adiyah, to meet the needs of the Bugis Wajo community for Islamic preaching at that time. At present, the Pesantren As'adiyah has developed into one of the largest pesantren in South Sulawesi. However, it is still carrying out halaqah as one of the characteristics of its independence. Halaqah is carried out every day after shalat magrib and subuh done, except Thursday night and Friday morning, in six different locations. Materials included are fiqh, hadith, aqeedah, akhlak, tasawuf and tafsir conveyed by the method of guidance, qira'ah tarjamah, lectures, and role models. There are two forms of dakwah halaqah As'adiyah in Sengkang, namely: 1) Mappesantreng that is coming directly to halaqah activities which are filled by Anregurutta/gurutta; 2) Halaqah da'wah through radio, which is to follow Islamic da'wah delivered by Anregurutta/gurutta through Radio Suara As'adiyah broadcasts.
\end{abstract}

Dakwah halaqah merupakan salah satu model penyampaian dakwah yang banyak digunakan dalam penyebaran dakwah Islam di Indonesia, sejak proses masuknya Islam, penyebaran hingga berkembangnya Islam. Pondok Pesantren As'adiyah Pusat Sengkang menjadi salah satu lembaga pendidikan Islam yang lahir dari sebuah pengajian halaqah yang dilaksanakan oleh anregurutta Fungngaji Sade, pendiri Pondok Pesantren As'adiyah, untuk memenuhi kebutuhan masyarakat Bugis Wajo terhadap dakwah islamiah saat itu. Saat ini, Pondok Pesantren As'adiyah Pusat Sengkang telah berkembang menjadi salah satu pondok pesantren terbesar di Sulawesi Selatan. Namun demikian, tetap melaksanakan halaqah sebagai salah satu ciri kepesantrenannya. Halaqah dilaksanakan setiap hari setelah selesai salat magrib dan subuh, kecuali kamis malam dan jumat subuh, di enam lokasi yang berbeda. Materi meliputi, fikih, hadis, aqidah, akhlak tasawuf, dan tafsir yang disampaikan dengan metode tuntunan, qira'ah tarjamah, ceramah, dan suri teladan. Model dakwah halaqah Pondok Pesantren As'adiyah Pusat Sengkang terdapat dua bentuk yaitu: 1) mappesantreng, yaitu datang langsung mengikuti kegiatan halaqah yang diisi langsung oleh anregurutta/gurutta; 2) dakwah halaqah melalui radio, yaitu mengikuti dakwah islamiah yang disampaikan oleh anregurutta/gurutta melalui siaran Radio Suara As'adiyah.

Keywords: As'adiyah, dakwah halaqah, pesantren.

\section{PENDAHULUAN}

Pesantren merupakan lembaga pendidikan Islam khas ke-Indonesia-an. Bagaimana pun asal mulanya, kini telah menjadi lembaga pendidikan dan keagamaan yang tertua di negeri ini yang tumbuh dan berkembangnya berasal dari masyarakat. Karena itu, pesantren memiliki sejarah 
yang cukup panjang walaupun tidak disebutkan kepastian kapan lahirnya pesantren tersebut ${ }^{1}$. Nurcholis Madjid mengungkapkan hal yangsama bahwa pesantren merupakan lembaga yang selain identik dengan makna keislaman, juga mengandung makna keaslian Indonesia (indigenous $)^{2}$. Pesantren merupakan lembaga yang sudah mengakar kuat dalam sejarah perkembangan Indonesia. Sehingga tidak salah jika dikatakan bahwa pesantren merupakan lembaga pendidikan Islam tradisional Indonesia.

Awal keberadaan pesantren di Indonesia sebagai lembaga pendidikan Islam yang tertua tentu saja tidak dapat dipisahkan dari sejarah penyebaran Islam di Indonesia. Pada awalnya, para penyebar agama Islam mendirikan masjid sebagai tempat mengerjakan salat jumat dan pusat dakwah islamiah, dan juga pada tiap-tiap kampung mereka mendirikan surau dan langgar. Di tempat tersebut mereka belajar salat dan mengaji dalam jumlah besar ataupun kecil. Mereka duduk di lantai menghadap sang guru. Hal seperti ini lebih dikenal dengan istilah halaqah ${ }^{3}$.

\footnotetext{
${ }^{1}$ Mahpuddin Noor, Potret Dunia Pesantren: Lintasan Sejarah, Perubahan, dan Perkembangan Pondok Pesantren (Bandung: Humaniora, 2006), hlm. 17.

${ }^{2}$ Nurcholish Madjid, Bilik-bilik Pesantren: Sebuah Potret Perjalanan (Jakarta: Paramadina, 1997), hlm. 17.

${ }^{3}$ Hasbullah, Sejarah Pendidikan Islam di Indonesia: Lintasan Sejarah Pertumbuhan dan Perkembangan. Cet. IV (Jakarta: Raja Grafindo Persada, 2001), hlm. 3-24.
}

Dengan demikian, halaqah pada awalnya merupakan kelompok pengajian dan pengkajian Islam serta pusat penyebaran dakwah yang selanjutnya berkembang menjadi lembaga yang dinamakan pesantren, sehingga keberadaan pesantren sebagai lembaga pengajian atau dakwah dan sebagai lembaga pendidikan sangat penting dan keduanya berupa kesatuan yang tidak dapat dipisahkan.

Pesantren sebagai lembaga pendidikan Islam tradisional mempunyai ciri khas yang berbeda dengan lembaga lainnya. Ciri khas yang esensial adalah adanya kiai yang mengajar dan mendidik serta menjadi panutan, santri yang belajar pada kiai, masjid sebagai tempat penyelenggaraan pendidikan dan salat jamaah, asrama tempat tinggal para santri, dan kitab kuning sebagai sumber ilmu dalam tradisi keilmuan pesantren ${ }^{4}$. Dari kelima unsur inilah yang kemudian menjadi ciri khas utama dalam sebuah pesantren.

\section{Pondok Pesantren As'adiyah} Sengkang adalah salah satu pesantren terbesar di Sulawesi Selatan yang awal mula didirikannya juga berupa pengajian dengan cara melingkar duduk bersila atau halaqah. Materinya khusus pengetahuan agama dan diberikan di salah satu ruangan

${ }^{4}$ Abuddin Nata (Ed.), Sejarah Pertumbuhan dan Perkembangan Lembaga-lembaga Pendidikan Islam di Indonesia (Jakarta: Gramedia Widiasarana Indonesia, 2001), hlm. 120. 
di rumah Anregurutta K.H. Muhammad As'ad, pendiri Pondok Pesantren As'adiyah Sengkang. Pengajian dengan sistem halaqah yang diberikan oleh Anregurutta K.H. Muhammad As'ad kala itu mendapat perhatian besar dari masyarakat Wajo maupun dari daerah lain. Hal itu ditandai dengan semakin bertambahnya santri. Mengingat jumlah santri semakin bertambah, maka pengajian dipindahkan ke Masjid Jami’ Sengkang 5 .

Pondok Pesantren As'adiyah selanjutnya mengalami perkembanganyang dulunya digunakan hanya halaqah, selanjutnya menerapkan sistem madrasah. Dengan sistem madrasah, Pondok Pesantren As'adiyah saat ini memiliki dua jenis pendidikan yaitu pendidikan yang mengkhususkan pelajaran agama dan pendidikan yang bercirikan pendidikan agama dan umum. Namun demikian, Pondok Pesantren As'adiyah masih tetap mempertahankan pelaksanaan halaqah dalam kajian kitab kuning dan dakwah. Selain itu, sistem halaqah di Pondok Pesantren As'adiyah Sengkang diberlakukan mulai dari tingkatan pendidikan tsanawiyah sampai tingkatan pendidikan tinggi. Pelaksanaannya dipisahkan untuk tiap tingkatan pendidikan, seperti, halaqah

5 Bahaking Rama, Jejak Pembaharuan Pendidikan Pesantren: Kajian Pesantren As'adiyah Sengkang Sulawesi Selatan (Jakarta: Parodatama Wiragemilang, 2003), hlm. 1. untuk tingkatan tsanawiyah, aliyah dan tingkatan pendidikan tinggi.

Adapun istilah halaqah di Pondok Pesantren As'adiyah lebih dikenal dengan istilah mappasantereng atau mangaji tudang yang diperuntukkan bagi semua kalangan santri dari tingkatan pendidikan sanawiah sampai tingkatan pendidikan tinggi dan dilaksanakan di luar jam pelajaran, yaitu setelah salat magrib dan setelah salat subuh. Sistem halaqah adalah kegiatan mappasantereng atau mangajittudang yang melibatkan unsur-unsur seperti, anregurutta/gurutta, santri, materi dari kitab kuning, dan metode-metode yang digunakan sebagai suatu komponen yang satu sama lainnya saling berkaitan.

Adalah hal yang menarik pada kegiatan pendidikan melalui halaqah ini, yaitu terdapat kegiatan dakwah yang dilakukan dengan mad'u berasal dari luar santri Pondok Pesantren As'adiyah Sengkang. Hal tersebut menjadikan As'adiyah sebagai lembaga lembaga pendidikan Islam sekaligus sebagai lembaga dakwah. Halaqah yang dilaksanakan akhirnya tidak hanya menjadi sekedar tempat belajar agama dan kitab kuning bagi para santri, tapi juga menjadi tempat menyebarkan ajaran Islam dan menimba ilmu bagi masyarakat Sengkang khususnya, dan Sulawesi Selatan umumnya. 
Berdasarkan fenomena tersebut, maka penulis tertarik mengangkat tulisan tentang dakwah halaqah Pondok Pesantren As'adiyah Pusat Sengkang. Tulisan ini merupakan salah satu bagian dari hasil penelitian penulis tentang sistem pembelajaran halaqah di Pondok Pesantren As'adiyah Pusat Sengkang. Adapun yang akan dibahas pada tulisan ini yaitu tentang pelaksanaan halaqah Pondok Pesantren As'adiyah, Metode dakwah yang digunakan dalam dakwah halaqah, dan materi dakwah dalamhalaqah Pondok Pesantren As'adiyah Pusat Sengkang.

\section{Pondok Pesantren As'adiyah}

As'adiyah adalah salah satu lembaga pendidikan Islam yang bergerak di bidang pendidikan dan dakwah islamiah yang dirintis oleh almarhum Al-'Allamah K.H. Muhammad As'ad yang dikenal dengan panggilan Anregurutta Pungngaji Sade. Beliau lahir di Kota Makkah pada hari senin 12 Rabiul Awal 1236 H/1907 M․ Beliau merupakan putra dari Haji Abd. Rasyid bin Abd. Rahman dan Hajjah. Shalehah binti Haji Teru yang merupakan keturunan ulama daerah Bugis-Makassar ${ }^{7}$.

\footnotetext{
${ }^{6}$ Muh. Yunus Pasanreseng, Sejarah Lahir dan Pertumbuhan Pondok Pesantren As'adiyah Sengkang (Sengkang: PB. As'adiyah, 1992), hlm. 42.

${ }^{7}$ Ummu Kalsum, K.H. Muhammad As'ad, Pendiri Pondok Pesantren As'adiyah Sengkang (Makassar: Alauddin Press, 2008), hlm. 14.
}

Pada usia 21 tahun, beliau tergerak hatinya untuk pulang kampung halamannya yaitu tanah Bugis Wajo setelah mendengarkan banyak berita tentang kondisi Masyarakat Wajo yang telah memeluk agama Islam. Namun kenyataannya banyak yang pengamalannya jauh dari akidah Islam yang sebenarnya. Masyarakat Wajo masih banyak yang percaya kepada berhala, khurafat, takhayul, taklid yang menyesatkan mereka. Selain itu, perjudian dan perampokan merajalela, masyarakat masih jauh dari ilmu agama. Dakwah islamiah sangatlah suram, masjid dan mushallah sepi dan kurang, madrasah belum ada. Kondisi ini menggerakkan hati beliau untuk kembali memperbaiki masyarakat dengan tujuan meluruskan akidah Islam yang telah rusak dan kembali ke al-Qur'an dan Sunnah Rasulullah ${ }^{8}$.

Saat beliau sudah di Sengkang Wajo, langkah pertama yang dilakukannya dalamdakwah islamiah ialah mengadakan pengajian dan ceramah, serta tidak lupa melakukan pendekatan kepada tokoh-tokoh masyarakat dan pemuka agama, dan pemerintah. Awalnya, beliau melaksanakan pengajian halaqah di rumahnya. Banyak masyarakat muslim di daerah itu berdatangan ke halaqah di rumah beliau untuk menimba ilmu agama. Suasana ini berlangsung lama hingga rumah beliau

8 Tim Penyusun, Ensiklopedia Islam (Jakarta: Ichtiar Baru Van Houve, 1993), hlm. 178. 
tidak dapat menampung lagi para santri yang belajar. Maka dipindahkanlah pengajian beliau ke masjid Jami'. Di sana berlangsung kajian-kajian Islam, sehingga para santri berdatangan dari berbagai daerah, dalam dan luar Sulawesi Selatan. Pengajian inilah yang kemudian menjadi cikal bakal lahirnya Al-Madrasatul 'Arabiyatul Islamiyah (M.A.I) Sengkang pada bulan Zulkaidah $1348 \mathrm{H}$ bertepatan bulan Mei 1930 M $^{9}$.

Sejak berdirinya Al-Madrasatul 'Arabiyatul Islamiyah (M.A.I) Sengkang pada tahun 1930, K.H. Muhammad As'ad juga sudah mulai memusatkan perhatiannya pada usaha mendidik sejumlah kecil santri, yang memang telah mempunyai bekal ilmu agama. Selanjutnya, merekalah yang menjadi santri senior dan membantu Anregurutta H. Muhammad As'ad dalam mengajar M.A.I.

Setelah kurang lebih empat tahun K.H. Muhammad As'ad mengadakan pengajian pondokan dengan cara duduk melingkar (tudang) atau halaqah, beliau pun menampakkan format dan pola pendidikan modern dengan menerapkan sistem klasikal dengan adanya tingkatantingkatan pendidikan, yaitu: 1) Al-Awaliyyah selama 1 tahun, (sebagai lembaga uji coba bagi calon santri yang dianggap

\footnotetext{
${ }^{9}$ Pimpinan Pusat As'adiyah, Setengah Abad As'adiyah 1930-1980 (Sengkang: Pimpinan Pusat As'adiyah, t.th.), hlm. 9.
}

sudah menerima pengajian pada tempat lain), 2) Tahdiriyyah selama 3 tahun, 3) Ibtidaiyyah selama 4 tahun, 4) Ie'dadiyah selama 1 tahun, 5) Sanawiah selama 3 tahun, 6). Kelas Khusus (Pengkaderan Ulama). Saat ini belum ada Aliah ${ }^{10}$.

K.H. Syamsuddin Badar, sebagai santri langsung Anregurutta H. Muhammad As'ad menceritakan tentang keberadaan beliau sebagai seorang pendidik dan pengajar, sebagaimana dituturkan kepada Yunus Pasanreseng bahwa saat itu,setiap hari Masjid Jami' Sengkang dijadikan sebagai pusat kegiatan pesantren, kecuali hari jum'at, setiap selesai salat subuh, magrib dan asar dilaksanakan pengajian halaqah yang dibawakan sendiri oleh Gurutta As'ad dan sesekali oleh santri senior, dengan berbagai kitab rujukan, seperti tafsir, hadis, fikih, tasawuf, dan sebagainya. Setelah selesai salat Isya, para santri melakukan tadarrus, muzakarah berbagai ilmu yang telah ada dan akan dipelajari, latihan muballiqh dan sebagainya. Waktu pagi sampai duhur dilaksanakan pelajaran madrasy. Usai salat duhur dihadapan mudarris pembantu, para santri mendalami ilmu nahu dan saraf secara kelompok untuk kemahiran berbahasa Arab dan membaca kitab gundul. Tepatlah dikatakan bahwa masa asuhan hadratussyekh tak ada waktu yang

\footnotetext{
10 Muh. Yunus Pasanreseng, Sejarah Lahir..., hlm. 38.
} 
dibiarkan lowong kecuali diisinya belajar dan mengajar berbagai ilmu agama ${ }^{11}$.

Dari penjelasan di atas dapat dipahami bahwa pada masa M.A.I dibawah asuhan Anregurutta. K.H. Muhammad As'ad, beliau sudah mengkader para santrinya untuk selanjutnya siap menjadi seorang ulama, dan semua itu berhasil dilakukan oleh beliau. Setelah menyelesaikan studi, kebanyakan santri beliau betul-betul mampu untuk mendirikan pesantren sendiri. Di antara pondok pesantren yang didirikan santri-santrinya dan menjadi pondok pesantren besar di Sulawesi Selatan ialah Pondok Pesantren DDI Mangkoso (Kabupaten Barru), didirikan oleh K.H. Ambo Dalle, Pondok Pesantren Yastrib (Kabupaten Soppeng), didirikan oleh K.H. Daud Ismail, dan Pondok Pesantren Al-Furqan (Kota ParePare), didirikan oleh K.H. Muhammad Abduh Pabbaja.

Setelah Anregurutta H. Muhammad As'ad wafat, tepatnya pada 29 Desember 1952, kepemimpinan Al-Madrasatul 'Arabiyyatul Islamiyyah (M.A.I) dipercayakan kepada K.H. Daud Ismail dan K.H.M. Yunus Maratan (1953-1961). Pada saat kepemimpinan berada di tangan beliau berdua, melalui musyawarah antara pembina, nama M.A.I. diubah menjadi M.A. (Madrasah As'adiyah) nama yang

11 Pimpinan Pusat As'adiyah, Setengah Abad..., hlm. 63-64. dinisbahkan kepada pendirinya, dan ini terjadi pada 25 Sya'ban 1372 H/9 Mei $1953 \mathrm{M}^{12}$.

Hingga saat ini, Pondok Pesantern As'adiyah telah berkembang pesat dengan melaksanakan pendidikan mulai dari jenjang pendidikan usia dini hingga pendidikan tinggi dan pengkaderan ulama. Pondok Pesantern As'adiyah memiliki pusat di Kota Sengkang Kabupaten Wajo dan telah memiliki banyak cabang di Sulawesi Selatan hingga ke luar pulau Sulawesi seperti Kalimantan.

Dari gambaran sejarah munculnya Pondok Pesantern As'adiyah, menjadi sebuah fakta sejarah bahwa pesantren ini lahir dari kebutuhan dakwah masyarakat Sengkang Wajo saat itu. Sehingga keberadaannya di masyarakat menjadikan Pondok Pesantern As'adiyah bukan hanya sekedar lembaga pendidikan semata, tetapi juga dapat dikatakan sebagai lembaga dakwah islamiah yang menjadi basis para daida'iah di Sengkang Wajo secara khusus, dan Sulawesi Selatan secara umum.

\section{Halaqah di Pondok Pesantren As'adiyah}

Defenisi halaqahdalam Ensiklopedia Islam Ringkas disebut halqah, yaitu kerumunan para pendengar yang duduk memutar mengelilingi seorang guru pada sebuah masjid. Istilah ini pada umumnya Abad..., hlm. 12 .
Pimpinan Pusat As'adiyah, Setengah
.
12 Pimpinan Pusat As'adiyah, Setengah 
dipahami sebagai para sahabat yang hadir dalam pengajaran Nabi Muhammad saw. Kata halaqah sering juga diartikan sebagai kumpulan penonton yang sedang menyaksikan pertunjukan atau sedang mendengarkan pembawa cerita $^{13}$. Sementara Amin Haedari berpendapat bahwa sebenarnya halaqah merupakan sebutan bagi situasi dan kondisi dimana sekelompok orang berkumpul untuk belajar di bawah bimbingan seorang kiai atau guru (Haedari, 2004: 18).

Adapun Istilah halaqah yang dilaksanakan di Pondok Pesantern As'adiyah diartikan sebagai kegiatan pengajian kajian kitab kuning yang dilakukan oleh anregurutta $^{14} \mathrm{dan}$ guru-gurutta ${ }^{15}$ dengan cara duduk di depan para santri/ santriwati/ mahasantri dengan menguraikan isi kitab. Kegiatan ini lebih dikenal dengan istilah "mappasantereng atau mangajittudang" yang diperuntukkan bagi semua kalangan santri dari tingkatan pendidikan tsanawiyah sampai tingkatan pendidikan tinggi dan dilaksanakan di luar jam pelajaran,

\footnotetext{
${ }^{13}$ Cyril Glassea, The Concise Ensyclopedia of Islam, terj. A. Mas'adi, Ensiklopedia Islam Ringkas, Ed. I. Cet. III (Jakarta: Raja Grafindo Persada, 2002), hlm. 123.

${ }^{14}$ Anregurutta adalah gelar kehormatan untuk ulama atau kiai di daerah Bugis, khususnya di Pondok Pesantren As'adiyah.Anregurutta mengandung arti tempat belajarnya orang-orang berilmu (ilmu agama).

${ }^{15}$ Guruttaadalahistilah atau panggilan untuk para pengajarsecara umum di Pondok Pesantren As'adiyah.
}

yaitu setelah salat magrib hingga masuk waktu salat isya dan setelah salat subuh.

1. Lokasi Halaqah Pondok Pesantren As'adiyah Pusat Sengkang

Pelaksanaan halaqah di Pondok Pesantren As'adiyah Pusat Sengkang dilaksanakan di beberapa tempat, sesuai dengan jenjang pendidikannya. Adapun lokasi pelaksanaan halaqah tersebut yaitu:

1) Masjid Agung Ummul Qura' Sengkang, halaqah mappasantereng untuk mahasantri Ma'had Aly As'adiyah sengkang.

2) Masjid Jami' Nurul Istiqamah, halaqah mappasantereng untuk mahasantri Ma'had Aly As'adiyah Kaltim, yang dilaksanakan setelah salat magrib dan salat subuh.

3) Masjid Jami Sengkang, halaqah mappasantereng untuk santri pada Madrasah Tsanawiyah putri Sengkang.

4) Masjid Al-Ikhlas Lapongkoda, halaqah mappasantreng untuk santri Madrasah Tsanawiyah Putra Sengkang.

5) Asrama as-Shalihah, halaqah mappasantreng untuk santri Madrasah Aliyah Putri.

6) Masjid Kampus Macanang, halaqah mappasantreng untuk santri Madrasah Aliyah Putra Macanang. 
Pelaksanaan halaqah atau mappasantreng di Pondok Pesantren As'adiyah Pusat Sengkang untuk saat ini, cenderung masih mengikuti tradisi yang diwariskan oleh para anregurutta sebelumnya, baik itu berhubungan dangan metode maupun kurikulumnya, meskipun ada beberapa perubahan yang dilakukan dalam pelaksanaannya. Itulah sebabnya, pada umumnya para pengajar halaqah masih menggunakan metode yang monoton, dimana mahasantri hanya menerima ilmu dan tidak ada timbal balik.

Halaqah menjadi rutinitas para santri Pondok Pesantren As'adiyah Pusat Sengkangdi semua jenjang pendidikan mulai dari Madrasah Tsanawiyah hingga Ma'had Aly. Halaqahdilaksanakan setiap selesai salat magrib dan salat subuh di masjid. Yang berbeda adalah halaqah yang dilaksanakan di Ma'had Aly As'adiyah adalah metode pembelajaran yang digunakan tidak persis sama dengan metode yang digunakan oleh guru-gurutta di halaqah-halaqahpada tingkatan lain, seperti halaqah untuk santri tsanawiyah dan aliyah. Selain itu, kitab/kurikulum halaqah Ma'had Aly juga berbeda karena pertimbangan level pendidikan yang lebih tinggi ${ }^{16}$.

16 Wawancara dengan Muhyiddin Tahir, 2014.
2. Metode Halaqah Pondok Pesantren As'adiyah Pusat Sengkang

Adapun metode pengajaran yang digunakan di halaqah Pondok Pesantren As'adiyah Pusat Sengkang adalah metode tuntunan, qira'ah terjemah, ceramah dan suri teladan.

a. Metode Tuntunan

Metode Dinamakan metode tuntunan karena santri menyimak kitab yang dibaca atau diajarkan oleh kiai dan kiai menuntun para santri dan membetulkan tanda baca atau harakat pada kitab yang diajarkan tersebut dengan membacakan kata per kata, kalimat demi kalimat dari isi kitab, kiai menerangkannya dengan menggunakan bahasa Arab, Indonesia ataupun bahasa daerah tertentu ${ }^{17}$.

Metode tuntunan pada halaqah Pondok Pesantren As'adiyah Pusat Sengkang terdapat dua bentuk yaitu: Pertama; halaqah terlebih dahulu diawali dengan meminta kepada santri/santriwati untuk membacakan materi kitab yang akan dipelajari hingga tuntas. Kemudian anreguruta/ gurutta membacakan ulang dengan membenarkannya. Kedua; anregurutal gurutta yang mengajar meminta santri/santriwati untuk membaca hlm. 160 .

${ }^{17}$ Bahaking Rama, Jejak Pembaharuan..., 
materi dan pada saat itu juga mendengarkan dan menegur jika terdapat kesalahan dalam bacaan santri/santriwati.

Untuk pembagian giliran membaca pada awal halaqah pada umumnya tidak ditentukan, seperti di halaqah madrasah tsanawiyah dan Aliyah. Menurut Samsul Nizar (2008), sudah merupakan kebiasaan bahwa santri/santriwatiyang lebih tinggi pengetahuannya duduk di dekat guru atau kiai. Murid yang lebih rendah dengan sendirinya akan duduk lebih jauh, sementara berjuang belajar keras agar dapat mengubah posisinya dalam halaqah ${ }^{18}$. Kondisi seperti ini menjadikan sebagian santri lebih dikenal oleh kiai dibandingkan santri yang lainnya. Hal tersebut menjadi penilaian khusus sang kiai.

Namun, bagi para mahasantri Ma'had Aly As'adiyah, bahwa pembagian jadwal mahasantri yang akan membaca pada halaqahdi mesjid didasarkan pada absen kelas, sehingga semua mahasantri mendapatkan giliran yang sama. Setiap mahasantri yang mendapat giliran untuk membaca, terlebih dahulu

${ }^{18}$ Samsul Nizar, Sejarah Pendidikan Islam Menelusuri Jejak Sejarah Pendidikan Era Rasulullah Sampai Indonesia.Cet. II (Jakarta: Prenada Media, 2008), hlm. 10. mempelajari bacaan kitab yang akan dibahas nantinya. Proses semacam ini, di Ma'had Aly As'adiyah, lebih dikenal dengan istilah "mattale" yaitu belajar dengan menelaah kitab dari segi cara baca, dan terjemahannya. Proses mattale' ini dilakukan dengan belajar bersama. Mahasantri yang mendapat giliran biasanya bertanya pada mahasantri yang lebih paham masalah nahwu dan sharaf, dan untuk masalah terjemahan kosa-kata, mereka mencari di kamus ${ }^{19}$.

Penerapan metode tuntunan pada halaqah Pondok Pesantren As'adiyah Pusat Sengkang memiliki dua bentuk, seperti yang disebutkan di atas, dan disesuaikan dengan kondisi santri/santriwati yang mengikuti halaqah. Perbedaan tersebut dapat dilihat pada halaqah di Masjid Agung Ummul Qura' yang diikuti oleh para santri dari jenjang Ma'had Aly dan halaqah yang dilaksanakan di masjid Jami Sengkang dan lainnya, yang diikuti oleh santri dari jenjang Madrasah Tsanawiyah dan Aliyah.

b. Metode Qira'ah Tarjamah

Selanjutnya, metode yang digunakan oleh anregurutta/ gurutta

\begin{tabular}{ccc}
\hline 19 & Nurfaikah, & 2014 \\
http://asadiyahpusatorg
\end{tabular}
http://asadiyahpusat.org. 
di halaqah Pondok Pesantren As'adiyah Pusat Sengkang adalah qira'ahtarjamah. Pada penerapan metode qira'ah-tarjamah ini, para santri/ santriwati terlebih dahulu membacakan kitab sesuai kemampuan mereka. Kemudian anreguruttal gurutta membaca kembali keseluruhan teks yang akan dibahas, selanjutnya memberi terjemahan kata per kata sesuai makna kontes bacaan, dan santri/ santriwati mencatat terjemahan tersebut di atas atau di samping teks dengan pulpen/pensil. Bahkan sebagian mahasantri ada yang menyiapkan catatan khusus untuk menuliskan penjelasan anregurutal gurutta tentang isi kitab yang mereka pelajari.

Adapun dalam menerjemahkan bacaan kitab kuning, anreguruttal gurutta dominan menggunakan bahasa Bugis meskipun ada yang menggunakan bahasa Indonesia. Sementara santri/santriwati menulis terjemahan kitabnya mengikuti terjemahan anregurutal gurutta. Namun demikian, pada umumnya santri/ santriwati menulis terjemahan bahasa bugis dengan menggunakan bahasa latin. Penggunaan bahasa Bugis dalam menerjemahkan dan menjelaskan kitab di halaqah merupakan tradisi Pondok pesantren As'adiyah, yang awalnya digunakan oleh Anregurutta K.H. Muhammad As'ad. Selain itu, penggunaan bahasa bugis di halaqah merupakan suatu upaya Pondok Pesantren As'adiyah dalam ikut serta melestarikan bahasa daerah.

c. Metode Ceramah

Sejak zaman Rasulullah metode ceramah merupakan cara yang paling awal dilakukan Rasulullah saw. dalam menyampaikan wahyu kepada umat $^{20}$. Metode ini juga disebut dengan metode tradisional karena sejak lama metode ini telah digunakan sebagai alat komunikasi lisan antara guru dengan anak didiknya dalam proses belajar mengajar, dan antara dai dan mad'u nya dalam dakwah islamiah.

Halaqah sebagai sistem transmisi dan geneologi keilmuan yang khas dalam komunitas pesantren menjadikan metode ceramah sebagai metode pengajaran yang utama. Metode ceramah merupakan suatu teknik dakwah yang banyak diwarnai oleh cirri-ciri karakteristik bicara oleh seseorang da'i pada suatu aktivitas dakwah. Metode ini harus diimbangi dengan kepandaian khusus

\footnotetext{
20 Armai Arief, Pengantar ilmu dan Metodologi Pendidikan Islam (Jakarta: Ciputat Pers, 2002), hlm. 136.
} 
tentang retorika, diskusi, dan factorfaktor lain yang membuat pendengar merasa simpatik dengan ceramahnya ${ }^{21}$.

Metode ceramah sangat dominan digunakan di halaqah Pondok Pesantren As'adiyah Pusat Sengkang. Anregurutta/gurutta menjelaskan secara rinci tentang kandungan kitab dengan menggunakan bahasa Bugis ataupun bahasa Indonesia. Sementara santri/santriwati menyimak dengan baik penjelasan tersebut. Metode pembelajaran seperti ini lebih dikenal dengan one way methode, yaitu metode satu arah, anregurutta/gurutta sebagai pemberi ilmu dan mahasantri hanya menerima. Untuk memahami apa yang terkandung dalam kitab, mahasantri cukup mempercayai bahwa penjelasan anregurutta/gurutta dari kandungan kitab itu pasti benar.

Pada saat penyampaian meteri kandungan kitab dengan metode ceramah ini, perhatian santri/ santriwati dalam menyimak materi yang disampaikan sangat tergantung pada kemampuan anreguruta/gurutta dalam menjelaskan. Beliau menggunakan bahasa Bugis saat menjelaskan

21 Amin dan Abdullah Hanif, ed. Masa Depan Pesantren: Dalam Tantangan Modernitas dan Tantangan Kompleksitas Global (Jakarta: IRD PRESS, 2009), hlm. 101. isi ceramahnya, khususnya di halaqah Masjid Agung Ummul Qura', karena halaqah yang dilaksanakan di masjid menjadi komsumsi masyarakat yang hadir dan tinggal setelah selesai salat subuh dan magrib.

d. Metode Suri Teladan

Islam adalah agama disiplin. Hampir seluruh ibadah-ibadah Islam mengandung unsur-unsur pengajaran dan latihan disiplin. Kewajiban untuk menunaikan salat dengan sarat-sarat, rukun-rukun, atau tatacara tertentu jelas mengandung pelajaran dan latihan disiplin. Begitu juga ibadah puasa, zakat, dan haji yang harus dikerjakan secara berdisiplin sesuai dengan tata cara dan waktu yang telah ditetapkan ${ }^{22}$.

Di halaqah, anregurutta/gurutta tampil sebagai orang yang memiliki kharisma dan diterima oleh masyarakat luas. Metode keteladanan tampak pada keteladanan dari diri anregurutta/gurutta dalam aspek ilmu, akhlak, ide-ide dan ibadah. Beliau mencontoh pribadi yang sejuk sehingga apa yang disampaikannya menyentuh di

22 Azyumardi Azra, "Transformasi Nilai Islam dalam Etika Sosial", dalam Nurcholish Madjid, ed., Kehampaan Spiritual Masyarakat Modern, Respon dan Transformasi Nilai-nilai Islam Menuju Masyrakat Madani (Jakarta: Media Cita, 2000), hlm. 389. 
hati para santri/ santriwati, dan masyarakat yang mendengarkan halaqahnya.

3. Materi Halaqah Pondok Pesantren As'adiyah Pusat Sengkang

Adapun materi halaqah Pondok Pesantren As'adiyah Pusat Sengkang adalah seputar fikih, hadis, akhlak tasawuf, dan tafsir. Materi tersebut bersumber dari kitab kuning yang menjadi kitab kajian para santri/santriwati. Klasifikasi kitabkitab yang diajarkan adalah, Kitab fikih terdiri dari Fath al-Mu'in, Muhazzab, Kasyifah al-Saja'. Kitab hadis terdiri dari Sahih al-Bukhari, Sunan Abi daud, Riyad al-Salihin, dan Bulug al-Maram. Sementara kitab akhlak tasawuf terdiri dari, Tanwir al-Qulub, Mau'izah al Mu'minin, Irsyad al-'Ibaddan Syarh al-Hikam, dan kitab tafsir yang diajarkan hanya Tafsir alJalalain.

\section{Model Dakwah Halaqah Pondok Pesantren As'adiyah Pusat Sengkang}

Keberadaan Pondok Pesantren As'adiyah Pusat Sengkang menjadi sebuah kebanggaan bagi masyarakat Bugis Wajo. Bagaimana tidak, As'adiyah telah melahirkan banyak ulama di Sulawesi Selatan yang menjadi pendiri pondok pesantren besar di Sulawesi khususnya, dan di Indonesia umumnya. Pondok Pesantren As'adiyah Pusat Sengkang merupakan lembaga pendidikan yang lahir dari proses dakwah islamiah, sehingga keberadaannya sebagai lembaga dakwah tidak dapat dipungkiri.

Salah satu model dakwah yang telah berkembang di Pondok Pesantren As'adiyah Pusat Sengkang yaitu model dakwah halaqah. Secara historis, pendiri As'adiyah, Anregurutta funggaji Sade, menyebarkan ajaran Islam melalui pengajian halaqah di rumah beliau. Hingga saat ini, halaqah masih lestari dan telah menjadi salah satu ciri khas Pondok Pesantren As'adiyah. Halaqah tidak hanya menjadi tempat memperoleh ilmu agama bagi para santri/ santriwati, tetapi juga oleh para masyarakat sekitarnya.

Halaqah sebagai sistem dakwah islamiah, menurut Enjang (2009), dilihat dari prosesnya lebih bersifat kontinyu, simultan dan intensif. Seperti halnya halaqah di pondok pesantren As'adiyah, anregurutta/gurutta yang membimbing santri dan masyarakatnya yang terus menerus dilakukan tanpa ada batas waktu tertentu. Anregurutta/gurutta melakukan halaqah rutin setiap hari di hadapan santri/santriwati dan jama'ah tanpa adanya batas waktu hingga lambat laun terdapat perubahan pada pemahaman dan praktik keagamaan jama'ahnya ${ }^{23}$.

${ }^{23}$ Enjang AS, Dasar-dasar Ilmu Dakwah. (Widya Padjajaran, Bandung, 2009), hlm. 54. 
Model dakwah halaqah di Pondok Pesantren As'adiyah Pusat Sengkang dibagi menjadi dua bentuk, yaitu:

\section{Mappesantreng}

Mappesantreng adalah bahasa Bugis yang yang asal katanya diserap dari kata "pesantren" dan mendapat imbuhan "ma" yang artinya datang mengikuti kegiatan pesantren atau menimba ilmu di pesantren. Kegiatan pesantren yang dimaksudkan disini adalah kegiatan halaqah atau pengajian kitab kuning yang diisi langsung oleh anregurutta/gurutta atau kiyai dan guru-guru senior di Pondok Pesantren As'adiyah. Istilah mappasantreng ini dikenal oleh santri/santriwati serta masyarakat Islam sekitar kota Sengkang, dan masyarakat bugis secara umum. Mappasantreng melalui halaqah sudah menjadi bagian penting dalam dakwah islamiah di Kab. Wajoyang dilaksanakan di enam lokasi yaitu Masjid Agung Ummul Qura’, Masjid Jami`Nurul Istiqamah, Masjid Jami' Sengkang, Masjid al-Ikhas, Masjid Kampus Macanang, dan Asrama Putri As-Shalihah.Ke-enam lokasi tersebut, lima diantaranya dapat diakses oleh masyarakat atau penduduk sekitar yang ingin menambah ilmu agama dari anregurutta/gurutta. Banyak masyarakat sengkang yang berdomisili di sekitar kota yang ikutmappesantreng. Pada awalnya, mereka hanya datang melaksanakan salat berjamaah magrib dan subuh, namun karena tertarik dengan materi dakwah yang disampaikan anregurutta/gurutta dalam halaqahnya, akhirnya tidak sedikit dari mereka yang memutuskan untuk ikut mendengarkan pengajian halaqahnya dan ikut mappesantreng.

Mappesantreng memiliki dua makna, yaitu mappesantreng sebagai kegiatan pendidikan dan mappesantreng sebagai kegiatan dakwah. Sebagai kegiatan pendidikan, mappesantreng menjadi kewajiban bagi para santri/santriwati untuk mengikutinya seperti halnya pendidikan di madrasah. Sementara, mappesantreng sebagai kegiatan dakwah islamiah, mer upakan kegiatan halaqah yang boleh diikuti masyarakat umum dan bebas bagi mereka untuk mengikutinya dengan hanya duduk ikut menyimak penjelasan atau ceramah para anregurutta/gurutta yang sedang melakukan pengkajian kitab kuning di hadapan para santri/santriwatinya.

Mappesantreng dalam konteks masa kini hampir mirip dengan model majelis taklim. Majelis Taklim merupakan bagian dari model dakwah sebagai tempat belajar untuk mencapai suatu tingkat pengetahuan agama. Departemen Agama RI (1991) merumuskan arti majelis taklim itu sebagai suatu lembaga yang menyelenggarakan pendidikan non-formal di bidang agama Islam bagi orang dewasa (adult 
education), dan secara berkala, sekali dalam seminggu, diadakan di majelismajelis atau di balai-balai pertemuan. Namun, mappesantreng sebagai sarana dakwah tidak membatasi jamaahnya dari segi usia ${ }^{24}$.

Adapun materi dakwah yang sampaikan pada halaqah mappesantreng adalah seputar fikih, hadis, akhlak tasawuf, dan tafsir. Materi yang disampaikan berbasis teks yang bersumber dari kitab kuning yang menjadi kitab kajian para santri/santriwati. adapun klasifikasi kitabkitab yang diajarkan adalah, Kitab fikih terdiri dari Fath al-Mu'in, Muhazzab, Kasyifah al-Saja'. Kitab hadis terdiri dari Sahih al-Bukhari, Sunan Abi daud, Riyad al-Salihin, dan Bulug al-Maram. Sementara kitab akhlak tasawuf terdiri dari, Tanwir al-Qulub, Mau'izah al Mu'minin, Irsyad al-'Ibaddan Syarh al-Hikam, dan kitab tafsir yang diajarkan hanya Tafsir alJalalain.

Dengan keberadaan mappesantreng yang terbuka dan bisa diakses oleh masyarakat sekitar sebagai tempat memperoleh ilmu agama, akhirnya menjadikan kegiatan mappesantreng sebagai salah satu bentuk model dakwah islamiah di Pondok Pesantren As'adiyah yang akan memberi kontribusi bagi peningkatan pengetahuan

${ }^{24}$ Departemen Agama RI, Pola Pembinaan Kegiatan Kemasjidan. Badan Kesejahteraan Mesjid (BKM) Departemen Agama Pusat (Jakarta, 1991), hlm. 8 . dan pemahaman keagamaan masyarakat sekitar khususnya Bugis.

2. Dakwah Halaqah melalui Radio

Radio merupakan alat komunikasi massa, dalam artian saluran pernyataan manusia umumnya/ terbuka dan menyalurkan gelombang yang berbunyi berupa program-program yang teratur dan isinya aktual dan meliputi seluruh segi kehidupan masyarakat $^{25}$. Sebagai media komunikasi, radio dapat digunakan juga sebagaimedia dakwah dalam menyalurkan pesan-pesan dakwah dalam arti yangluas. Penggunaan radio sebagai media dakwah sudah banyak dilakukandi Indonesia, baik melalui radio swasta maupun radio komunitas, baik melalui radio satelit maupun radio internet.

Penggunaan radio sebagai media dakwah dilakukan oleh Pondok Pesantren As'adiyah Pusat Sengkang. Radio Suara As'adiyah menjadi media atau corong dakwah Islamiah Pondok Pesantren As'adiyah Pusat Sengkang yang mengudara sejak tahun 1969. Radio Suara As'adiyah telah menjadi menjadi pelopor radio dakwah di Sulawesi dengan menjadi radio pertama di kawasan Bone Soppeng Wajo dan sebagai salah satu radio tertua di Sulawesi Selatan (Arsip Permohonan Perpanjangan izin Penyelenggaraan PenyiaranLembaga Penyiaran Swasta

\footnotetext{
25 Anwar Arifin, Dakwah Kontemporer (Yogyakarta, Graha Ilmu, 2011), hlm. 108.
} 
Jasa Penyiaran Radio PT. Radio Suara As'adiyah Sengkang Kab. Wajo).

Radio Suara As'adiyah (RSA) didirikan oleh pengurus besar As'adiyah sebagai radio yang berorientasi syiar dakwah islamiah. RSA saat ini mengudara pada frekuensi FM 103.2 Mhz. RSA dari awal mengudara telah menjadi trend setter masyarakat wajo. Dalam hal menentukan waktu salat, mereka selalu menunggu azan dari Masjid Agung/ Masjid raya yang disiarkan oleh RSA sebagai acuan masuknya waktu salat. Masyarakat seolah tidak percaya pada jam waktu masuknya salat yang dimiliki pengurus masjid. Demikian pula dengan kegiatan halaqah atau mappesantreng, RSA menjadi media yang memperluas penyampaian pesan dakwah kegiatan mappesantreng.

Halaqah melalui Radio Suara As'adiyah menjadi salah satu model dakwah yang dikemas di Pondok Pesantren As'adiyah Pusat Sengkang. Halaqah Pesantren As'adiyah Sengkang disiarkan live dua kali sehari oleh Radio Suara As'adiyah, yaitu setelah salat magrib dan salat subuh. Penyiaran halaqah Pondok Pesantren As'adiyah Pusat Sengkang menjadikan kegiatan pengkajian keagamaan Islam memiliki jangkauan yang luas dan dapat dikomsumsi oleh masyarakat Wajo bahkan sampai di luar Provinsi Sulawesi Selatan. Halaqah yang awalnya terbatas bagi para santri/santriwati dan jama'ah sekitar, berubah menjadi halaqah banyak dan tidak terbatas jumlah dan ruangnya.

Pada dakwah halaqah melalui RSA, anregurutta/gurutta menggunakan bahasa Bugis saat menjelaskan isi ceramahnya, khususnya pada halaqah yang dilaksanakan di Masjid Agung Ummul Qura', karena halaqah yang dilaksanakan di masjid tersebut bukan hanya menjadi komsumsi masyarakat yang hadir dan tinggal setelah selesai salat subuh dan magrib, tetapi karena halaqahnya disiarkan secara langsung oleh Radio Suara As'adiyah (RSA). Masyarakat di luar sana ikut menilai kemampuan pengajar halaqah dalam memaparkan isi kitab, dan mereka lebih senang dan lebih paham jika penjelasannya menggunakan bahasa Bugis. Masyarakat di luar yang mendengarkan ceramah halaqah melalui siaran Radio Suara As'adiyah (RSA) pada umumnya adalah masyarakat awam dan mereka biasa melakukan protes dan tidak senang terhadap pengajar yang banyak menggunakan bahasa lain selain bahasa Bugis.

\section{KESIMPULAN}

Pondok Pesantren As'adiyah merupakan salah satu pondok pesantren tertua dan 
terbesar di Sulawesi selatan. Pesantren ini lahir dari sebuah kegiatan pengajian halaqah yang dilaksanakan oleh Anregurutta Fungngaji Sade, pendiri Pondok Pesantren As'adiyah, di rumah beliau dengan tujuan dasarnya melakukan dakwah islamiah kepada masyarakat Wajo saat itu yang berada pada masa degradasi akidah dan moral meskipun telah memeluk agama Islam. Dengan demikian, Pondok Pesantren As'adiyah Pusat Sengkang tidak hanya mengemban tugas lembaga pendidikan Islam, tetapi juga mengemban tugas dakwah islamiah.

Pelaksanaan halaqah Pondok Pesantren As'adiyah Pusat Sengkang dilaksanakan setiap hari setelah selesai salat magrib dan subuh, kecuali kamis malam dan jumat subuh. Lokasi pelaksanaannya ada enam, yaitu Masjid Agung Ummul Qura' Sengkang, Masjid Jami' Nurul Istiqamah, Masjid Jami Sengkang, Masjid Al-Ikhlas Lapongkoda, Asrama as-Shalihah, dan Masjid Kampus 2 Macanang.Materi halaqah meliputi, fikih, hadis, aqidah, akhlak tasawuf, dan tafsir yang disampaikan dengan metode tuntunan, qira'ah tarjamah, ceramah, dan suri teladan.

Model dakwah halaqah Pondok Pesantren As'adiyah Pusat Sengkang terdapat dua bentuk yaitu: 1) mappesantreng, yaitu datang langsung mengikuti kegiatan halaqah atau pengajian kitab kuning yang diisi langsung oleh anregu- rutta/gurutta atau kiyai dan guru-guru senior di Pondok Pesantren As'adiyah di enam lokasi yang dimiliki; 2) dakwah halaqah melalui radio, yaitu mengikuti dakwah islamiah yang disampaikan oleh anregurutta/gurutta pada halaqah Pondok Pesantren As'adiyah Pusat Sengkang dengan mendengarkan melalui siaran Radio Suara As'adiyah. Dakwah halaqah melalui radio ini, banyak diikuti oleh kaum muslimin dan para simpatisan As'adiyah di Kabupaten Wajo dan sekitarnya.

\section{DAFTAR PUSTAKA}

Amin, Samsul Munir. 2009. Ilmu Dakwah. Jakarta. Amzah. 2009.

Ali, Mohammad.1993. Strategi Penelitian Pendidikan. Bandung: Angkasa.

Arief, Aramai. 2002.Pengantar ilmu dan Metodologi Pendidikan Islam.Jakarta: Ciputat Pers.

Arifin, Anwar. 2011. Dakwah Kontemporer. Yogyakarta, Graha Ilmu.

Azra, Azyumardi. 2000. "Transformasi Nilai Islam dalam Etika Sosial", dalam Nurcholish Madjid, ed., Kehampaan Spiritual Masyarakat Modern, Respon dan Transformasi Nilai-nilai Islam Menuju Masyrakat Madani. Jakarta: Media Cita.

Departemen Agama. Pola Pembinaan Kegiatan Kemasjidan. Badan Kesejahteraan Mesjid (BKM) Departemen Agama Pusat: Jakarta, 1991.

Ejang, AS. 2009. Dasar-dasar Ilmu Dakwah. Widya Padjajaran, Bandung. 
Ensiklopedia Islam, 1993. Jakarta: Ichtiar Baru Van Houve.

Glassea, Cyril. 2002. The Concise Ensyclopedia of Islam, terj. A. Mas'adi, Ensiklopedia Islam Ringkas, Ed. I. Cet. III; Jakarta: Raja Grafindo Persada.

Haedari, Amin dan Abdullah Hanif, ed. 2004.Masa Depan Pesantren: Dalam Tantangan Modernitas dan Tantangan Kompleksitas Global. Jakarta: IRD PRESS.

Hasbullah. 2001. Sejarah Pendidikan Islam di Indonesia: Lintasan Sejarah Pertumbuhan dan Perkembangan. Cet. IV; Jakarta: Raja Grafindo Persada.

Kalsum, Ummu. 2008. K.H. Muhammad As'ad, Pendiri Pondok Pesantren As'adiyah Sengkang. Makassar: Alauddin Press.

Madjid, Nurcholish. 1997. Bilik-bilik Pesantren: Sebuah Potret Perjalanan. Jakarta: Paramadina.

Nata, Abuddin. ed., 2001. Sejarah Pertumbuhan dan Perkembangan Lembaga-lembaga Pendidikan Islam di Indonesia.Jakarta: Gramedia Widiasarana Indonesia.

Nizar, Samsul. 2008. Sejarah Pendidikan Islam Menelusuri Jejak Sejarah Pendidikan Era Rasulullah Sampai Indonesia.Cet. II; Jakarta: Prenada Media

Noor, Mahpuddin. 2006. Potret Dunia Pesantren: Lintasan Sejarah, Perubahan, dan Perkembangan Pondok Pesantren. Bandung: Humaniora.

Passanreseng, Muh. Yunus. 1992. Sejarah Lahir dan Pertumbuhan Pondok Pesantren As'adiyah Sengkang. Sengkang: PB. As'adiyah.

Pimpinan Pusat As'adiyah Sengkang, Setengah Abad As'adiyah 1930-
1980. Sengkang: Pimpinan Pusat As'adiyah, t.th.
Rama, Bahaking. 2003. Jejak Pembaharuan Pendidikan
Pesantren: Kajian Pesantren As'adiyah Sengkang Sulawesi Selatan. Jakarta: Parodatama Wiragemilang.

http://asadiyahpusat.org. 
Besse Wahida:

Dakwah Halaqah Pondok Pesantren As'adiyah Pusat Sengkang 